\title{
The Possibility of a Transnational Public Sphere \& New Cosmopolitanism within the Networked Times: Understanding a Digital Global Utopia: “Avaaz.org” and a Global Media Event: "Freedom Flotilla"
}

\author{
Basak Sarigollu \\ Izmir University of Economics \\ Faculty of Communication \\ Department of Media and Communication \\ basak.sarigollu@ieu.tr \\ basarigollu@gmail.com
}

\begin{abstract}
The $19^{\text {th }}$ and $20^{\text {th }}$ centuries have been structured with full of struggles to reshape and define a new state model. Each territory fought for specifying its own dimensions, rules and regulations, values and certain ways of collective thinking that are determined with reference to an ethnic root. This struggle lasted for decades and for some generations the constitution of a state meant blood, starving and for many it meant tears. The output of such efforts had been the so called glorious nation states of the last century. In fact, the concept did not only lead to some regulations and sharing with reference to an ethnic common past but also to the notion of the nation state that has bore the promises of: common good, administration of citizens in the most possible democratic ways under the concept modern citizenship (which concerns mainly the constitution), moral- material security and welfare. Such promises of the early $20^{\text {th }}$ century have been celebrated with the hope of emancipation and democracy. They had been glorified with the hope of Enlightenment, certain effects of the liberal economy and with the project of modernity.
\end{abstract}

As a matter of fact, through various changes in the social global arena which has witnessed the two disastrous World Wars, the demise of the liberal economy and social- security systems, the power and the ongoing structure of the nation states had been started to be questioned. The transnational corporations, global agreements, and transnational organization which in a way deconstructed the solid premises of nation states, offered both to the citizens and to the leaders of the World something new. This was something more flowing, something 
that both challenged the existing ways of administration and the current definitions of time, space, citizenship and identity. Through the rise of globalization with the compression in time and space by the new communication technologies and the neo- liberal (new social) movements, the certain ways of doing, certain codes and certain rules were not only challenged but also had shown the people all around the globe that there are alternatives to the patterns that they are familiar with.

Such a shift both in terms of ideology and sociology questioned the belonging that citizens construct with their states. The actual possibility of multiple belongings were defined not territorially nor ethnically, but had been fed by the new communication technologies that so practically redefined the actuality of time, space and identity. A vast number of people all around the globe started to live lives that are networked and were allowed to share their own dreams of emancipation through that certain networks by not only being in function but also by taking action locally and globally.

This paper, by following such discussions questions the possibility of a transnational public sphere in a networked society and the concept of the new cosmopolitan identity within the times of network societies. By studying two cases: an international issue between Israel and Turkey that through new media technologies turned out to be a global phenomenon: the case of "Freedom Flotilla" (Mavi Marmara) and a digital network : "Avaaz.org”, both seem so practically eager to reflect the new cosmopolitan identity; that is recently discussed within the political science literature, the paper examines the possibility and feasibility of the concept and its promising capacity of global emancipation by referring to Habermas's public sphere and Kant's cosmopolitanism through new communication technologies and network societies.

Keywords: new cosmopolitanism- transnational public sphere- network societies- new media 


\section{The Transformation of Habermas and the Transformation of Public Sphere}

Habermas's optimistic but promising concept of 'Public Sphere'(1962) has been celebrated by many social scientists as the network of new information technologies: the internet, has been oficially beneficial for various global social movements, disastours and in couple of global events (wars and international relations) maybe not as a total determinator of final results of how those events terminated but as a practicle tool that enables certain civil political agents and global groups to assert their possition by declaring their purposes and sides. The interactive space between the state and the society is defined as closer than ever within such definitions. Whereby, the new global civic networks fits to the definition partially, as they are now, if successful; the interactive network between the global, the local, media (themselves and other mediums) and the public. In fact, today, global civil networks are not merely proposed as the area of public discussion but also the actual arena for public political action; the operation of the public opinion.

The new order of world, clearly has changed and has been challenged by various factors of; the transformation of our long time understanding of actual time and space, operation and the value of information, the definition of the capital and the capital order following the new global rules, the nature of labor, democracy, identity and the political order...

It is a fact that we all must accept without a doubt; not everything and everyone is globalized. The digital, social and financial divides, resistance and tradition are still a part of immobile identities. The system, as a web of connected lines and correlations, rationally refuses any kind of incapability within its well-communicated structure. Thus ; yes, not everything is globalized but everything and everyone is affected by the globalization. So, the issues that humankind face should never remain local and of their own. In fact the celebration of such flows and profound change in the order of life must be rewarded to end inequalities, suffer and violence of the mankind. The 'includeds' (mobile agents) thus, as holding the current means of power; information, must work for the lacking other; the 'excludeds'. Within such a belief, the new definitions of political global powers, nation state, civil society and media politics regulates the exciting possibilities of democracy, social movement and dissemination of power through collective action. It can be fairly admitted that state is not the pre- given, unique political unit or single force of power within the system of network societies. In fact it 
is in a reserved idea of democracy through the new tools and definitions of global democratic orders and their influences on the destinies of the local geographies. Although the land and their geography are still very meaningful for most of the people, they fight, protest and gather within digital spaces through the flows of spaces for their localities. Many people and populations have grasped the significance of acting both locally and globally. Local civil actors are in fight of fulfilling the gap that many nation states failed to successfully satisfy. Through such a process, the non- governmental social networks claim to be the actors, the advocators of needs, interest and values of localities and were obligated to reflect their cry to the global networks and powers.

\section{Avaaz: A Cry for the Other?}

Avaaz was one of the responses to these thousands of local cries. The global civic network took action in January 2007 with the claim of being a global online advocacy community to bring people powered-politics to the global decision making. Their aim is not only to change the so called dictatorship of power or powerlessness but also to vitalize the old leftistactionist soul. The mission of the network has been declared as to "organize citizens to help everywhere to close the gap between the world we have and the world most people want." The name of the site ironically means "to scream" as it sounds the same in many Middle East countries. Avaaz asserts to have 4.9 million registered members all around the globe and a network at a reach of 70 million people through mails, phone calls and request for action. The population of the global network has reached a number of a small country where the global, viral and other types of media usage and campaigns are considered may reach a triple of its number. The network seems to gather crucial aspects of the global social action;

1)Population: Avaaz uses the advantage of its 4,9 population in generating pressure upon political leaders, opinion leaders to communicate with transnational organizations and political, economical cooperation both to legitimize and blackmail the power of nation state rulers. Through petitions and signatures the network defines political desire and democratic demands of thousands while the network also guides the citizens to pressure their leaders locally. Mancur Olson, (1971) suggests that in every political action systemization of population results with success. Olson states that: 
"group pressure alone determine the final equilibrium tended to be just and desired. As the pressure groups would be week in the first place, they would be divided in those circumstances they would easily ask to much from the leaders as their members also ha overlapping membership in other groups with different interests and within various positions"(124).

The second reason for the significance of numbers is that such groups bear the potential of being collective costumers and voters for the nation states and economies. Thus risking such a huge amount of financial or political protest would constitute feature problems (1971:125). Knowing the power of numbers, Avaaz's executives uses the networks of other members through communicating TNCs, TNOs and super national political organizations through their political and social recognition and management of the network system.

2) Media: The well-organized usage of the new media can alter the information flows through mass media. By various media campaigns, creative productions and political advertising broadcasted and published nationally and globally (BBC, Voice of America, CNN, Liberation FR, Washington Post, Financial Times, European Voice, The Guardian, New York Times, etc) the network aims to create global awareness, interest and support and legitimate their actions to be taken towards the issues in local and global senses to activate the World population for various humanitarian causes. According to Bennett in (Donk, Loader, Nixon and Rucht, 2004: 140) New media provide alternative communication spaces in which the information can develop and circulate widely with fewer conventions or editorial filters that in the mainstream media. Such new practices alter the ways the mass media operates. Many journalists, opinion leaders and broadcasters seek the stories, coverage and problems of both global and very local digital mediums in order to feed their stories and news coverage. According to Bennett, the viral political communication is now very important as flows of information both operates from micro to macro levels (Bennett, 2003c; Manheim: 2001). The image and framing of movements are much related with the strategies that the social activist groups interact with the media gate- keeping. What Bennett suggests is that personal relations remain very important in the process of gluing the movement to larger audience through mass media. Referring to the protest in Seattle against WTO Bennett, claims that also the capacity 
of activist leaders to enable direct communication and news making is crucial for the success of the movement.

Following those discussions, Avaaz's success on reaching millions of people and gaining its recognition as the most populated and well-known digital social network, has been very much related with its well-known executives positioned within eleven centers all around Europe and USA. Rick Pantel, with his impressive background and various roles in activist movements well managed the networking system of the online social network through creative campaigns. As Ruch (2004:48) depicts, the role of creativity and sympathy in gaining political awareness within the new social movements, had been advance. These social networks performed their protests with weird costumes, tools that signify both popular culture products and their own messages. In fact, what Avaaz, did with various campaings was to create a kind of public strategy through creative pr products like their protest on climax change through the Matrix figure of World leaders, calling their attention and naming their power through "world is in your hands". Such a campaign both highlighted the responsibility of the leaders against the public eye and enabled mass media appearance for the network.

3) Mutual operation in space and place: Avaaz, claims to take its actions both locally, geographicly and online. The network claims to take 10,000 actions considering rallies, flash mobs, vigils, marches and online events for local and global causes of human rights, environmental issues and lack of democratic operation. In fact as Ruch depicts, the digital social networks mainly fails to be sufficiently influential in localities and actual places:

"It seems that the internet is an important facilitator of information and mobilization, but it cannot replace the personal contacts among the key organizations, protestors and campaigns."(2004:51)

Ruch, relates this fact with the loss of identity as such diverse groups of floating subjects gather for global purposes: the identity, trust and communion between the physical protests lack power and tension. On the other hand, what he states is meaningful as most of the actions of Avaaz operate through petition, member letters, signatures and donations. 
4) Identity: Avaaz, addresses an identity of the ideal "leftist" dream, a society in piece and equality. People of the world are in power, against the national and global forces through "gathering", "collective action" and "sharing the wealth". The components of the movement resemble "revolution" and thus optimistically or not, it promises a salvation against powerlessness of the individual within the new global order. Ruch, defines the emergence of a "New left" identity after the 1960s students' movements. The new left identity has been constructed within discussion groups and journalism schools whom have been gathered around the Marxist literature and intense debates about the correct ideological line of the World Order (2004:40). Such an awaking in diverse parts of the World, led to the tradition of counter- publics mostly among students. In fact, the tradition with the transnational movements against neo- liberal globalization have became a civil union among the leftist identity both online and offline to deconstruct the false consciousness of millions and anti humanitarian order of the global structure.

\section{A New Cosmopolitan Community?}

Although civil engagements are claimed to be in decline as individualism becomes pre dominant in the current times, criminal networks, feminist groups, environmentalists, ethnic groups, fundamentalists organizations, construct their own civil networks to make their voice heard, assert their identities and negotiate power both through local and global legitimization and political and public awareness of their suffer, demands and rights. Through media usage and global public awareness these groups threaten the nation states with their voting behavior or consumption practices (politically or economically). By the globalization of media politics, efficient social movements are expected to operate through networks of action and operation for global and local justice. These movements have been the actions of public opinion mostly practiced "epistemologically" harshly against suppressing governments and leaders. In fact such a definition of global citizenship and ethical, humanitarian mission fits well with the ideology of new cosmopolitanism. As Pnina Werbner depicts that new cosmopolitanism believe in the mediating role of digital civil networks and in the power of civil entities in altering the political positioning of states through the pressures of civilian power $(2008: 215)$, Werbner views cosmopolitanism within various definitions like the working-class cosmopolitanism, ethic cosmopolitanism, and discrepant cosmopolitanism. Hence all the 
definitions of cosmopolitanism basically, must cover, "worldwide double-interdependency encompassing any local particularity" (2008:14). In fact the new vernacular cosmopolitanism concerns more with the cosmopolitan ethnicity which refers to the identity within post colonial states about citizenship, equal dignity, cultural rights and the rule of the law. Referring to Kwame Anthony Appiah (1998), Werbner argues that:

"cosmopolitanism is a membership of morally and emotionally significant communities that constitutes a inclusive political project of creating alliances between like- minded individuals and collectivities" This project is rooted and involves: “ restless quest for further horizon; the imperative of moral-centering; the constructing and transcending of difference"(2008:15).

Furthermore, cosmopolitanism has been associated with the "travelling person" in Immanuel Kant's definition of cosmopolitan identity. In fact, Werbner, argues that new cosmopolitanism does not interfier with mere elitest identities (2008:24). Werbner illustrates an example of a Pakistani migrant working in a building side of Gulf. She defines him as: "a simple man who embraces different cultures and members of diverse groups, but who never retains his transnational yet rooted identity as Sufi” (2008:16).

Establishing such a cosmopolitan identity definition, Avaaz also illustrates the transformation of the bourgeois public sphere of Jürgen Habermas (Calhoun:1999) which at first was conceptualized as :

"a new kind of space in which rational critical discussion by citizens, rather than sheer economic logic or the instrumentalists of state power could assist in the formation of state policies and civil, political and social rights"(Calhoun,1999:33).

Although, the critical approaches against the theory had been on its lack of emphasis of transformational possibilities of the space and the real limitations of those spaces, within years, Habermas's public sphere, gained the notion of being a transnational public sphere which demands one of the crucial elements of globalization and social movements. The transnational public sphere is understood as "action at a distance" and it occupies specific places and communities. Thus the possibility of transnational public sphere is through: 
"various localized applications, potentially quite distant from the original production of the discourse or practice in question" (Guidy, Kennedy, Mayer, Zald, 2000:7)

The search of a global, ethical and humanitarian identity of empathy and transnational public sphere through various flows in spaces and in a practice of actual places basically, defines the identity and operational structure of Avaaz. In fact, the digital social network site bears real potential of creating a leftist project identity (Castells: 2004) through its appropriate self definition, mission and vision parallel to the new order of the World.

Whereby, what seems lacking or insufficient within the structure is the focus on localities and local problems before the conflicts turn out to be global through the informational and political flows.

The digital social network basically, focuses on the global agendas that constitute a broad space on public discussion or global news coverage. Avaaz sent electronic letters to the members and called them to protest through reaching 200,000 petitions, right after the Freedom Flotilla constituted by seven ships from different countries with 750 passengers from 40 nations with the company of 35 international politicians have been attacked by Israel in international waters on its way to transporting aid to Gaza which has been under the blockage of Israel within the past three years. Avaaz, as a global organization lacks using the benefits of its population, media acces and political recognition by focusing on unrevealed local confilicts and operates more globally with already globalized and legitimized issues. The organization may be influential in activating global movements and keeping alive the "new cosmopolitan" identity, in fact it seriously ignores realities of the less included groups to the network which should have been the leading missions of the digital social organization.

\section{Mutually Global, Mutually Local: Flows Of Spaces, Media Politics, Networked Identities and the Questions of Nation State}

On $30^{\text {th }}$ of May 2010, a ship; Mavi Marmara has departed with activists from Turkey with its passengers and various foreign intellectuals to meet with seven other ships departed from Britain, Ireland, Algeria, Kuwait and two other ships from Turkey, which at total carry a 
number of 750 people of civil citizens from forty countries including thirty- five international politicians, well known civil rights activists, academicians and intellectuals. The international group named their movement "Freedom Flotilla" and defined their mission as the breaking of the Israeli- Egyptian blockage. The group described their aim on only transforming the badly needed aid to the people of Gaza whom have been living under blockage for the past three years and repeatedly mentioned their lack of political, religious, martial bonds and purposes on reaching Gaza. Even to the various threats announced by the Israeli government, the group declared their consistency on reaching to Gaza by seriously risking their own lives.

On the night of May $31^{\text {st, }}$ Israel had operated a military attack on the seven ships caring 10,000 tons of aid, concerning: reconstruction materials, medicine, toys, and food and daily care products. The attacks had been broadcasted alive from the portable media stations on the Freedom Flotilla, depicting the uneven use of violence of Israeli soldiers with killing nine of the Turkish civilians and seriously injuring twenty. The reporters and people on the ship have continued their live broadcasting and transmitted the event all around the World by their transmitters. In fact, Israel government have got the control of the "Freedom Flotilla" and arrested the passengers. The event has got huge thrust all around the globe by constituting the headlines in international news bulletins. In fact the movement did not succeed and had been the live example of state's power on controlling affairs, violence and even self determined territories while establishing the utopian side of new cosmopolitan understanding.

However the case has multiple sides, as Appadurai, Castells and Harvey all define differently under communication, information technologies and capitalism. Freedom Flotilla must be understood within the intersection point of various flows of spaces(from actual geographical localities to networking spaces), identities(from Islamic fundementalism to cosmopolitan "world citizenship"), the role of media and the transnational organizations which under the pot all together defines the power of the "powerfull state" with comperance to power of cosmopolitan community, civil society and social movements.

As within the historical transformation of our times some say 'passing of modernity' (Harvey: 1990, Appadurai: 2006) and others call as 'late modernity', the 'information age' (Castells: 2000) 'the network society' (Castells:2004) the emergence of a new social 
foundation is related vastly with the change in the mode of production, technological innovations which constitute the new ways of transformation of times and spaces and the change in the media- communication systems with the new media and its politics. According to Castells (2004), the main definer of individual and collective cognition has been the significant shift in the times and spaces which all together led to the emergence of the network society. Castells, defines the actors of the current society as the flows of spaces and the timeless time. Based on, social theory, the space is defined as the material support of time sharing social practices. Fallowing such argument, the development of communication technologies can be understood as the "gradual decoupling of continuity and time sharing" (2004: 36). The space of flows is the possibility of technological and organizational action within the network societies that enable global financial markets, media networks, networks of global governance and global social movements.

In fact the gradual meaning of space does not ignore the fundamental need of places and localities. On the contrary, the actual places of geography, localities and regions are what really constitute the meanings of spaces and their flows. Castells depicts that:

"the space of flows is not placeless. It is made of nodes and networks; that is, of places connected by electronically powered communication networks"(2004: 36).

What really makes the networks possible and meaningful is their base on localities and how they function as well as their role to the specific other networks within the space of flows. Thus as meaning changes within the spaces, space cannot be separated from the social practices; there are different definitions of spaces within the flows of information, politics, media and finance.

Freedom Flotilla action, as a part of "Free Gaza" movement have been in various spaces which each referred to different localities, networked spaces (center of localities of the social action), a global space (global networks, arena, politics) and a actual locality; Gaza. Such variations of spaces illustrate the integration of various networks within each other, connecting various spaces and places with a gradual identity and meaning. 
First of all, the actionist groups did not sprang from the actual lands and geographies of the occupied territory (although Hamas can be counted as a resistant community, the case concerns the movement of Freedom Flotilla) but from various different localities all around the globe that through the nods of spaces and networking practices constitute a resistant action upon the resistance or exclusion of the "other". Such an identity is only constituted within and upon believing in the preservation of all human rights, concerning all kinds of equality, activating upon the violation of human rights and systematically as well as unequally distributed power practices. Following the discussions of Pnina Werbner (2008), the definition of such an identity relates mostly to the "cosmopolitanism" which is defined as; "an ethical horizon- an aspirational outlook and mode of practice"(47). Whereas cosmopolitanism, insists on the human capacity to see the world from an 'other's perspective, and imagine the World with a borderless pulurality.

As the activist identity is very much related with the term and the movement, it should be explained in detail that: what the 'New Cosmopolitanism' refers to. First of all, the new cosmopolitanism, has been proposed by David Held, inspired by Immanuel Kant's "Perpetual Peace" that argued the possibility of utopian cosmopolitan citizenship. In fact, Held conceptualizes the possibility of that utopia not under political but social terms under such a definition of identity through the globalization of information, flows of time, space and the capital. Following the discussion of Held, Werbner (2008) reveals that the first factor which determines the concept as; global governance and democratization. Focusing on Kant, Werbner, argues that; people do exercise violence upon the lands of each other. The power holder gains cruelity upon other lands as a global governance is lacking. Thus what enables the democratization is not exactly the consciousness of mankind but the uniting of law and governmental procedures. Hence, new cosmopolitanism conceptualize democratization as the first and most crucial factor of the new global order in order cosmopolitan citizens to internalize the right of the other and global law to enable and protect the equality of rights and individual security (22).

The second order of new cosmopolitanism can be summarized by referring to Habermas's 'public sphere' where he emphasized on the power of NGOs and their struggle to highlight the recognition of the protection of the global peace and all human rights which within their 
lack the world is led by ethnic violence, civil wars and collective torture on nations by other nations.

The last order of new cosmopolitanism is what precisely defines the identity of global activist and their movements. Werbner states that; new cosmopolitanism is a personal consciousness, a choice instead of an obligation or necessity of the globalization. In fact, the identity is defined accordingly by the belief in democracy and social rights of all human beings and civilians' power to protect them (2008).

The definition of a new cosmopolitan identity and its vast practice in the new social actions, movements and networks has a lot to do with the consequences of globalization and self definition of more mobile identities. The analyzes on the global intellectuals and their responsible struggle on broader emancipation and protection of other localities' rights and well being are very much concerned with defining one's self as a "global citizen" that links both his and other's localities.

In fact globalization does never come to mean a homogenization but a pluralization and fragmentation of places, identities, spaces where through the bounds, a web like system is constituted to define the networks that enable broader and broader networks with their mutual combination. Thus, through witnessing the systematic violence that even may be named as massacre by suppressing all the infrastructure of a city, avoiding the entrance of food, reconstruction and medicine in Gaza, the "global citizens" of the society gathered around an "new cosmopolitan identity" to protect and preserve the rights of other localities. In fact, the actual illustration of the event represented as a celebration of the shifts, flows and spaces with reference to Manuel Castells' term 'resistance identity' (2000) which he related with the exclusion of the excluded. Hence, the resistance this time has been the call from 'includeds' within the network. The call for democracy and human rights was a civil movement, promoted by the usage of digital media networks which is defined by Juris, as:

"the best way to balance freedom with coordination, autonomy with collective work, self organization with effectiveness" (2004:355). 
Juris, suggests that the networking is a tool for creating social fabric in local contexts to generate the World people wants. So the main point in digital and social networks is working locally and thinking globally. In fact the Free Flotilla case constitutes the locality and globalization within the flows of spaces through networking practices of global network system with "Ship to Gaza" and their locality of Sweden which is also in a web of other networks with various localities like Turkey: "Insani Yardım Vakfi" which arranged the local protests, communion and communication of the action within Turkey along with other localities all around the World.

The flows of spaces within the action such as Gaza, Sweden, Cyprus (Free Gaza Center), Britain, Ireland and various spaces within those countries around the globe enables the flows of identities. As mentioned above, the meaning of place is still evident in defining the flows of spaces where each space is diverse and unique. Thus, multi spaced nature of the humanitarian action is constructed through the identities of various networks and NGOs which linked on the bases of "helping Gaza". Insani Yardım Vakf1 (IHH), has been constituted in 2006 coinciding with the time that Gaza has been put on blockage by Israel. The NGO basically defines its mission by humanitarian causes. Whereby the organization is known for its Islamic Fundamental roots, it repeatedly neglected any depictions on its cause of action as the Islamic Brotherhood. In fact, IHH defines its mission as "to reach and offer humanitarian aid for all needy people any time, without concerning geography or identity with our understanding of brotherhood." The organization highlighted to provide "all people, humanitarian aid and brotherhood" through bold characters while depicting its foreign name as "The Foundation for Human Rights and Freedoms and Humanitarian Reliefs". As following Castells' advice of: social movements are what they say they are (2004), It should be depicted that the organization claims to be almost in every locality (From Middle East to Africa, Far East to Caucasia, United States to Asia) on earth except Europe (only in Solovenia and Hungary).The organizational language is densely Islamic and their collective activies also concern performing the salaat or praying. Following Castells' analysis and arguments on Islamic Fundamentalism, in the first chapter of "The Power of Identity" (2004), it should be suggested that the identity of the network and action of IHH densely contains the Islamic brotherhood with the idea of Umma and martyrdom. IHH gathered in Turkey mainly focusing at Bursa, Antalya and Istanbul; a vast amount of people through aid nights, protests, 
discussion groups under the identity of Islamic brotherhood; Umma. The meetings were mostly held in the more conservative parts of the city like Umraniye, Fatih and Esentepe. Most of the passengers of Mavi Marmara believed in the idea of martyrdom as Israel have send its official threats of attack, the passengers declared that they risked their lives and consented on their own death on such a holy mission. The nature and doctrines of Islam not only suit well with the definition of globalization following the idea of Umma but also Turkish Islamic Fundamentalism to be the guardian of all Muslims around the Globe to celebrate the caliphate dream which makes this action more meaningful within network identities.

The existence of different localities and identities like the fundamentalist, intellectual, new cosmopolitan are significant to emphasize on the plurality and flows of spaces, identities with their unique definition and how they manage to meet at nods of networks to success on a geographical action through virtual and local gathering.

In fact, the crucial point here is that as Kennedy and Zald celebrate in "Globalization and Social Movements" (2004:13), Werbner (2008) agrees on with the concept of the "new transnational public sphere' in "the Antropology and New Cosmopolitanism" and Castells depicts three main orders for the social action or movement to be sucsesfull ; 1)construction of an identity: as a social cement and durability of the movement, 2) media usage and network integrity: to legitimize the political action within the global and local arena and pressure the political powers, 3) the support of entellectuals: to universaly gain sympathy and emphaty for the action through clever communication tecniques and practices, the "Freedom Flotilla" did not achieve its mission of transporting Gaza the 10,000 tons of global aid pacage.

The successes of the social action has been limited with a global live broadcast of systematic violence of Israel in international waters to civil activists from children to old women which enable the problem of Gaza and violence of Israel to be taken at a more global and political level. Even to the massive agenda setting and news coverage on all well respected channels like BBC, CNN, ABC, Channel 5 and high networking activity in digital spaces with cyber protests in digital social networks (Avaaz), the action remained unsolved in political level. 
The political pressure with exploration of UN and EU had remained in unofficial terms through the representatives of the organizations where various presidents of nation states like Barack Obama had declared that they felt "truly sorry". Whereas, the action mostly affected Turkey with the murder of nine citizens and local protests had taken place in various places. What is crucial to underline here and also what constitutes the core point of the discussion is that there are various networks which all hierarchal differ with reference to their ability of political pressure to transnational powers and through that nation states and are politically linked with leading powers of both financial, social and political flows (Juris,2004) like EU, UN and as a nation state USA being above all the states that are positioned in the global arena which mainly define the fortune of the social action. What makes networks valuable in an era of information age, is not only their high population but also their ability to attain challenge on the political powers and pressure transnational organizations through including their agents within the powerful, political networks (351).

According to Manuel Castells, the states are powerful as long as they have control over spaces and times (2004:243). Castells (2004), argues with the increasing speed of global flows of space and time through services, technology, information, communication, goods and capital, states lack their old ultimate power of dominant control over its citizens while also lacking the strong national identities through plural, mobile identities of network society. In fact Castells suggests, through the lack of managing global economies, providing social security and a meaningful identity to most of its citizens, states lost power and ended up with searching power in reasserting their forces in global arena by super national institutions that undermines their sovereignty. Castells depicts that:

"The formation of European Union was not a process of building the European federal state of the future, but the construction of a political cartel, the Brussels cartel, in which European nation-states can still carve out, collectively, some level of sovereignty from the new global disorder, and then distribute the benefits among its members, under endlessly negotiated rules.”(2004:267)

Certainly states did not lose their total power of being the dominant guardians of the local territories and they also still remain with their influence on citizens. What really happened was the lost of nation state's unquestionable legitimacy upon its people or land to a very 
small extend through the pressure of transnational organizations controlling financial and political flows, NGOs and civil society by influencing the global citizens to pressure their own rulers for global negotiations or activating local protest against the problematic government.

As David Held argues that:

"the international order today is characterized by both the persistence of the sovereign state system and the development of plural authority structures. The objections to such a hybrid system are severe. It is open to question whether it offers any solutions to political thought which have been preoccupied by, among other things, the rationale and basis of order and toleration, of democracy and accountability of legitimate rule"'(1991:161)

Held stresses out in his argument that: nation states are still not powerless within the current global older. Nor there is a possibility of global governance in the sense of new cosmopolitanism. In fact what only seems possible is that the idea of humanism, global empathy and a two way flow of democracy. In fact, globalization and the network society through the flows of spaces, information, services and the capital enables a three step model of democracy including the social networks, NGOs and transnational organizations to investigate the rights of local but also global citizens through the humanitarian identity of new cosmopolitanism. Jane Roger (2008) in "Spatializing Politics" also highlights the maintenance of state power through the significance of actual places and state territories as:

"the spatial logic of territoriality and assumptions of territorial primacy prevail, despite the many challenges posed to this perspective. Despite the nuances of analysis of international politics today, conceptions of political legitimacy of 'real' politics start with states and work down from there. States, as the 'possessors' of territory, continue to be seen as the defining political unit. Whether the state is the most important or powerful actor is not the issue here. What is significant is the way the positioning of one actor as dominant establishes the categorization and perceived relevance of others."(2003:64) 


\section{Concluding Remarks}

That is what the case of Freedom Flotilla illustrated for the citizens of global orders. First of all the, eventhough there is a high flow between spaces, either Appadurai (1996) names as 'scapes', Virilio (1997) as 'interval of spaces' or Rodger (2008) as 'spatial', through technology, communication systems, networks and high mobility of people, services, information and capital, these flows of spaces are not there to remain within the nods of spaces but actual places; geographies that still matter the most for the human kind. As Julie Peteet depicts in "Landscape of Hope and Despair: Palestinian Refugee Camps" (2005), the people of our times still live within the dream of a certain land, a actual place to call home as they seek a sense of belonging both ethnically and geographically. Countries like Israel knowing the value of a land, a home to call a nation's own, consciously and systematically erases the sense and idea of belonging of Palestinian people to a land. Thus even though there are continues flows in times and spaces the actual localities and geographies are still crucial.

Furthermore, localities; places, are also significant in terms of social movements to take actual practices in local places like were done in Antalya, Istanbul and Bursa. Even though social scientists like Arthur Edwards, (in Donk, Loader, Nixon and Rucht,2004:198) glorifies the online movements and highlights the sufficiency of virtual space as a real space that enable protest, gathering and communication, localities still matter for both as homelands, places of protest, values and within the definition of identities (Islamic brotherhood).

Secondly, even though there is a wise and active usage of digital spaces, networks, localities and media, the lack of political legitimization within the global political arena still disables the rights of civil movements which highlight the still existing power of the nation state. The solution within such a problem in the case of Freedom Flotilla, should have been legitimizing its action through lobbying and high networking practices with TNO,TNC and other leading figures of the Global system. Lance Bennet, (in Donk, Loader, Nixon and Rucht,2004: 150) suggests that networking practices and media appearance of a social action is for legitimizing the action beforehand, where Freedom Flotilla missed to practice or limitedly practiced with thirty-five international politicians and intellectuals and their civil declarations of good offices. Lobbying with EU members or UN and in fact having the 
"bless" of the USA, would lead to the success of the action if such a strong networking would be possible.

Thirdly, although, the global social action under new cosmopolitan identity of transnational public sphere (Werbner, 2008) and civil society is meaningful within the mediating role of the state which has been under the direct pressures of neo- liberalism to change its political position and enable possibilities for civil society to engage transnational advocacy for global human rights, states, more or less constitute their dominant power by increasing the diversity and efficiency of their military forces, budgets and policies to protect their so called sovereignty even risking to stand against the global powers and transnational organizations. What is worthy of underlining is that among the global legitimization through media, what matters the most is the power of the state to stand among the global capital flows, against informational and security crises by its friends and against its foes to remain the ultimate power for some more time within the World history until the "new cosmopolitan" dream comes true. The power or connectedness of a state is now the crucial determiner of its position against the civil society and social pressures.

Furthermore, the celebration of networking is also an innocent one when realizing the great power of surveillance that information society gifts to the databases of security councils of the national state. (Castells, 2004) Through networking systems which still are in the hands of the national governments; the most powerful agent of all times military and our times; information are still in the hands of the nation state. Even there are hopes, new structures (TNC,TNO,NGO) and epistemology (new cosmopolitanism) for the free practice of civil society and cosmopolitan citizenship, the celebrations are relatively early as seen within the current global examples.

What must be questioned and carefully investigated within the coming years is the possibility of a "new cosmopolitan community" within the digital spaces that value to the local as much as the global rather than focusing on the globalized local issues. A belief and search for true "cosmopolitan" identity as the operator of the flows between the spaces and places within the transnational public sphere would be meaningful as Habermas's term "public sphere" was not totally practical in early $20^{\text {th }}$ century and lately became meaningful within such flows that 
enable to speak of free flow of information and discussion. As this paper is written strongly by the motivation of evaluating the novel possibilities of responsibility to address and heal 'other's wounds, it addresses the salvation within a practical dream of a common hope: 'new cosmopolitanism': a new definition of identity, which will be more feasible as maybe someday, at some degree, if all sorts of global actors learn empathy through touching the localities and even searching for localities that are offline within the network society. 


\section{REFERENCES}

Appadurai, A. (1996c) Modernity At Large: Cultural Dimensions of Globalization. University of Mineapolis Press: USA.

Calhoun, C.( 1999) Habermas and the Public Sphere. MIT Press: London.

Castells, M.(2000). The Rise of the Network Society. Blackwell: USA.

Castells, M. (2004) The Power of Identity. Blackwell: UN.

Castells, M. (2004b) The Network Society: A Cross-Cultural Perspective. Edward Elgar Publishing: USA.

Donk W,Loader B, Nixon P, Rucht D.(2004). Cyberprotest: New Media, Citizens and Social Movements. Routhledge: New York.

Guidy J, Kennedy M, Zald N. (2000). Globalizations and Social Movements: Culture, Power and the Transnational Public Sphere. The University of Michigan Press: USA

Habermas, J. (1961). The Structural Transformation of the Public Sphere:An Inquiry into a Category of Bourgeois Society. Polity: Cambridge.

Harvey, D. (1990). The Condition of Postmodernity: An Enquiry into the Origins of Cultural Change. Blackwell: Cambridge.

Held, D. (ed) (1991). Political Theory Today. Polity Press and Stanford University Press: USA.

Held, D. (2003). Cosmopolitanism: A Defence. Polity Press: Cambridge.

Juris, Jeffery S. (2004). Networked Social Movements: Global Movements for Global Justice (in) The Network Society: A Crosscultural Perspective. Edward Edgar: Chentenham.

Olson, M. (1971). The Logic of Collective Action. Harward University Press: London.

Peteet, J. (2005). Landscape of Hope and Despair: Palestinian Refugee Camps. University of Pennsylvania Press, 2005.. University of Pennsylvania Press: USA.

Rodger, J. (2008) Spatializing International Politics: Analysing Activism on the Internet. Routhledge: New York.

Virilio, P. (1997) Open Sky. Verso: London.

Werbner, P.(2008) Anthology and the New Cosmopolitanism. Berg: New York. 